\title{
Alternative Futures and Future Alternatives for the Philosophy of Education: Introduction to the Symposium
}

\author{
Gert Biesta $^{1} \cdot$ Michael Peters $^{2}$
}

Published online: 24 September 2015

(C) Springer Science+Business Media Dordrecht 2015

The three papers brought together in this invited symposium reflect on the future of philosophy of education, considering future alternatives and alternative futures. What is perhaps most striking about the three contributions is that they reflect on the future of philosophy of education from three distinct geographical locations. Peter Roberts, based in New Zealand, reflects on philosophy of education with an eye on developments in his own country, in Australia and in the wider region served by the Philosophy of Education Society of Australasia. Heesoon Bai and colleagues, based in Canada, take the situation in North America as their point of departure, albeit that their reflections aim at a truly global perspective. Christiane Thompson reflects on developments in Germany and the German speaking context which, although located in Europe, is distinctively different from developments in other European countries, particularly those influenced by philosophy of education as conceived and practiced in the English speaking world (see Biesta 2011, 2012, and also 2014).

Reflection on philosophy of education and its future is, of course, not something that should occupy a central place in scholarship in the field, but from time to time it is important to take stock as to where the field is going and what its particular challenges and opportunities are. In doing so it is even important to consider what 'the field' actually stands for and is 'about,' because behind the label 'philosophy of education' we cannot only find a wide array of different approaches - as one would expect from healthy, philosophically-informed scholarship_-but also different views and conceptions of what such scholarship is or should be about, including the ongoing question whether philosophy

Gert Biesta

gertbiesta@gmail.com

Michael Peters

mpeters@waikato.ac.nz

1 Department of Education, Brunel University London, London, UK

2 WMIER, Faculty of Education, University of Waikato, Waikato, New Zealand 
of education should be understood as a sub-field of philosophy or mode of applied philosophy, of whether it is a branch of educational scholarship or, as what is particularly an option in the German speaking context, part of education as an academic discipline in its own right. (In this regard we point the reader particularly to some of the footnotes in the contribution by Christiane Thompson that highlight some of the difficulties of translating the nomenclature of German 'Pädagogik' into English.)

Raising questions about the current state and future of philosophy of education is particularly relevant, as all three contributions argue in their own way, from the perception that philosophy of education, both as an institutional field and as an intellectual endeavour, is facing a number of challenges. Peter Roberts documents what we might term the rise and fall of philosophy of education in his region, noticing that whereas institutionally the state of philosophy of education is worrying, intellectually it can be said to be quite vibrant. The issues he identifies with regard to the institutional position of philosophy of education are not unique for New Zealand and Australia but are felt in many other countries around the world, partly as a result of similar neo-liberal and performative pressures on the academy (see, for example, Smeyers et al. 2014). Heesoon Bai and colleagues engage more explicitly with the intellectual challenges for philosophy of education, particularly highlighting the need for intercultural work so that philosophy of education can not only escape from its own biases but actually contribute to the task of building bridges across different cultures. Interestingly, Christiane Thompson puts the idea of philosophy of education as being in crisis in a much wider historical perspective, thus suggesting that in some sense philosophy of education has always suffered from a certain marginalisation, highlighting the fact that the relative distance of philosophy from 'the tides of daily existence' is both a prerequisite for doing proper philosophical work in education and is seen as a problem, particularly with regard to the relevance of such work for education.

Although Peter Roberts makes a strong plea for the institutional strength of philosophy of education and argues that it remains important to fight for its place in the universityincluding in teacher education programmes - he also makes a case for a more 'dispersed' mode of operation, not only by arguing for the need for philosophers of education to establish alliances across the spectrum of educational scholarship and research, but also for focusing our attention on the ethos of philosophy and philosophy of education-an ethos that can emerge in many different places and that can be fostered both within and outside of the academy. Such a wider conception of what philosophy of education is and where it might 'occur' makes him slightly more optimistic about the future of the field than if the focus were to be exclusively on the institutional state and position of philosophy of education.

That there is a need for a vigorous, more open intellectual programme for philosophy of education is also the view for the future that Heesoon Bai and colleagues propagate. As mentioned, they particularly highlight the need for philosophy of education to become more plural but also see an important role for philosophy of education to embrace this plurality and make connections across cultures - both philosophical cultures and cultures more generally. Both Bai and colleagues and Roberts connect the ethos of philosophy of education to learning processes-learning from difference, cultural learning, or, in the case of Roberts, a commitment to a process of lifelong learning.

Where Roberts and Bai and colleagues focus on philosophy of education as practice and ethos within the wider realm of educational scholarship, Christiane Thompson provides us with a view of the future of philosophy of education that is more specifically seen as a critical factor vis-à-vis the wider field of educational research itself and the field of education policy making. Here there is a particular need to expose and criticise often hidden 
assumptions and dynamics that are often presented and understood by researchers and policy makers as benign and as orientated towards the improvement of education but which, on closer inspection, reveal tendencies that raise fundamental questions about the conceptions of improvement - and even the conceptions of education - that are being utilised and articulated. Here philosophy of education first and foremost represents a critical 'voice' vis-à-vis research and practice although, through this, it also has implications for the everyday conduct of education.

The contributions to this symposium thus provide us with an interesting range of options and observations. Although the authors are all concerned about philosophy of education and its future, they do highlight different concerns and, through this, different views about what philosophy of education is, ought to be or might be. We find it useful to bring these different views together, and leave it to the reader to bring the pieces into conversation with each other as a starting point for further exploration of the meaning and significance of philosophical work in and on education. We do not think that there is a need to make a choice about the 'position' of philosophy of education-that is, whether it should be seen as part of educational scholarship primarily aimed at educational practice or more as a meta-activity primarily aimed at educational scholarship itself-and, in this regard, do see the views presented in this symposium as complementary (although we do think that the position articulated by Thompson raises some further and quite important questions about the centrality of learning in the direction that Roberts and Bai and colleagues seem to propose; see also Bingham in press; Biesta 2015). In any case we do hope that the contributions in this symposium help those who work in philosophy of education or whose work exemplifies the ethos of philosophy of education find both inspiration and direction for their own work, and also find helpful arguments for positioning this work institutionally within the wider field of educational scholarship. This is not because we believe that philosophy of education can only exist within the university-on this point we agree that the ethos of philosophy of education can be present in many contexts and settings. But a robust institutional presence and representation remains important, particularly for the educative ambitions of philosophy of education - that is regarding the unique contribution it can make to the education of teachers, educational researchers and educational 'workers' in other domains - and for the reproduction and most importantly ongoing renewal of the field itself.

\section{References}

Biesta, G.J.J. 2011. Disciplines and theory in the academic study of education: A comparative analysis of the Anglo-American and continental construction of the field. Pedagogy, Culture and Society 19(2): $175-192$.

Biesta, G.J.J. 2012. Wanted, dead or alive: educationalists. On the need for academic bilingualism in education. In Positionierungen. Zum Verhältnis von Wissenschaft, Pädagogik und Politik, ed. C. Aubry, M. Geiss, V. Magyar-Haas, and D. Miller, 20-33. Weinheim: Beltz Verlag.

Biesta, G.J.J. 2014. Is philosophy of education a historical mistake? Connecting philosophy and education differently. Theory and Research in Education 12(1): 65-76.

Biesta, G.J.J. 2015. Freeing teaching from learning: Opening up existential possibilities in educational relationships. Studies in Philosophy and Education 34(3): 229-243.

Bingham, C.W. (in press). Against educational humanism: Rethinking spectatorship in Dewey and Freire. Studies in Philosophy and Education.

Smeyers, P., D.J. De Ruyer, Y. Waghid, and T. Strand. 2014. Publish yet perish: On the pitfalls of philosophy of education in an age of impact factors. Studies in Philosophy and Education 33(6): 647-666. 